\title{
Not Measured Tumor Identification
}

National Cancer Institute

\section{Source}

National Cancer Institute. Not Measured Tumor Identification. NCI Thesaurus. Code C103425.

The identification of a tumor that is present at baseline and will not be quantifiably measured over the course of the study. 